\title{
Do Diversity of Directors Improve Market Performance
}

\author{
Zerni Melmusi ${ }^{1}$, Desi Ilona ${ }^{1}$, Elfiswandi1 ${ }^{1}$, and Ade Kurniawan ${ }^{2,3}$ \\ ${ }^{1}$ Lecturer, Faculty of Economics, Universitas Putra Indonesia YPTK Padang, Indonesia \\ ${ }^{2}$ Master Student in Management, Universitas Putra Indonesia YPTK Padang, Indonesia \\ ${ }^{3}$ Staff PT. Semen Padang.
}

\section{Abstract}

Purpose: The main aims of this study to examine whether diversity of directors will improve market performance in emerging market, especially in Indonesia.

Methodology: A number of variables associated to diversity of directors are gender, ethnic, and skill diversity of directors. Panel data analysis is used for 90 companies listed in Indonesia from 2013-2016 periods.

Findings: Ethnic diversity of directors appears to influence Indonesian company market

Corresponding Author:

Desi llona

ilonanadlif@yahoo.co.id

Received: 18 January 2019

Accepted: 24 March 2019

Published: 31 March 2019

Publishing services provided by

Knowledge E

(c) Zerni Melmusi et al. This

article is distributed under the

terms of the Creative Commons

Attribution License, which

permits unrestricted use and

redistribution provided that the

original author and source are

credited.

Selection and Peer-review under the responsibility of the First ELEHIC Conference Committee.

\section{G OPEN ACCESS} performance negatively when using Tobin's $Q$ as a proxy.

Originality: This research has an original benefit to corporate governance aspect by investigating the association between diversity of directors and market performance in Continental European system.

Keywords: corporate governance, diversity, market performance

\section{Introduction}

Researches on Board of Directors charactheristics and company performance have received much intention until now [1]. Board of Directors has a significant contribution in enhancing value of stakeholders. Their contribution is depend on diversity of board members such as gender, ethnic, and skill [2]. Diversity of directors means that difference in background of directors members in a company [3]. According to [4], higher diversity of directors produce more idea in decision making. Thus, it is important to explore diversity of directors in enhancing better market performance. Therefore, this study has led to introduce this issue in Indonesia that adapt Continental European system in the area: directors' diversity. It is because diversity of directors has several benefits to market performance [5], [6], greater innovation [7], and improve quality in decision-making [8]. 
In recent year, diversity directors have attracted much attention of researchers, but most of prior studies focus on gender diversity [9-12], diversity in human and social capital [4]. Most prior researches have been done in Anglo-Saxon system such as [13]. In addition, most prior research focus on the relationship between diversity of directors and company performance [2] and the finding of that study is still in questionable [14]. However, there is limited study that examine diversity of directors, especially in Indonesia. However, little finding exists on the association between diversity of director as measured by gender, ethnic, and skill of directors and market performance in developing market.

\section{Literature Review}

Indonesia was colonized by Netherlands. Further, some of Indonesia's system follow the Netherlands, including Corporate Governance system. There are two types of board in Indonesia's Corporate Governance system that are Supervisory Board (Dewan Komisaris) and Board of Directors (Dewan Direksi). However, the Supervisory Board is poor in controll and monitor the management's action and less effective in their role [15]. This condition produce high information asymmetry among both Boards; Board of Directors and Supervisory Board [16]. Thus, it impact on conflict not only between principals and agents [17], [18], but also between the Supervisory Board (agent) and the Board of Directors (agent). To reduce this conflict, it needs Board of Directors who have better knowledge and quality in manage the company in order to improve market performance. Quality of directors could be presented through diversity of directors (Board of Directors). [19] believe that quality decisions could improve when there is diversity in a groups.

Most of prior studies that investigate directors diversity use resources dependence theory [13], [20-22]. The current study exploits agency theory in investigating diversity of directors and market performance. From agency theory, there is unalign the interest between Supervisory Board and Board of Directors [16]. Thus, the current study investiagtes diversity of directors (Board of Directors) could enhance alignment of the interest both boards and the market performance of Indonesia listed companies. Thus, agency theory is used in this study.

Prior research of [4] use data from Asian tourism market; China, Hong Kong, Thailand, Malaysia, and Singapore. The sample of the study is 85 companies for 20012011 periods. They found diversity of directors in human capital and social capital has insignificant effect on company performance. [23] focused on experience, education, and age of independent directors diversity and company performance. The result shows 
the proportion of independent directors with goverment experience is positive significant on company performance. However, the percentage of independent directors as a accountants has a negative effect on company performance. For age diversity and academic background diversity of independent directors have positive impact on company performance.

\subsection{Gender diversity}

Almost directors are from man members [1]. Most of prior study in emerging market find the number of women on board is still low such as in Indonesia [24], [25] and Malaysia [13]. Some researchers believe that companies with a significant women directors tend to improve the number of customer [12], increase board effectiveness in information flow and decision making [26], better financial performance and corporate governance practices [27]. Vice versa, one of researchers believe that the presence female directors do not give value to company [28]. However women on board will give positive contribution to board room due to they are more disipline, honesty, and cool down in problem solving than men.

Previous studies that exaamine the effect of gender diversity and performance of company show mix resuts. [29] find that the presence women directors has a negative effect on ROA but a positive effect on EPS. Studies in the US show mixed results. [30] examine women on Top Management Team (TMT) and the Board of Directors to company performance. They find that presence women on the TMT and the Board of Directors have no relationship with company performance. [5] employ 638 Fortune 1,000 companies. They find the proportion women directors has a positive effect on company performance. [31] use the Fixed Effect Generalized Least Square Regression for 122 quoted Nigerian companies from 1991-2008. They find gender diversity has a negative and significant impact on company performance. [12] focus on gender diversity in top management and boardroom for 54 large Colombian public companies in period 20082015. They find adding women in top management and boardroom have a positive impact on business performance as measured by Return on Assets (ROA) and Return on Equity (ROE).

Thus, the hipotesis of this study can be writed as bellow:

H1: The presence of gender diversity on Board of Directors improve market performance. 


\subsection{Ethnic diversity}

Indonesia's population consists of more than 300 distinct ethnic with the largest ethnic is Javanese (40\%). Javanese has major contribution in political environment. The other ethnic is Chinese. According to [13], Chinese directors have great leadership skill as professional manager and successful in developing their business. Eventhough, the number of Chinese Indonesia's population is around 3 percent but they are dominated in business and controlling most of the Indonesia's wealth [32]. Some advantages of the presence ethnic diversity on Board of Directors are better governance [33], enhance the effectiveness of directors' action [31] and produces positive outcome [34]. Thus, ethnic diversity of directors create diversity in value of directors in the area; diffrent atitude, experience, and perspectives on society which can give a positive impact on market performance.

[34] examine the effect of gender and ethnicity diversity of CEO and audit committee members on audit delay for 1,642 US companies. They find that gender and ethnicity diversity of CEO and audit committee are related with shorter audit delay. Using a panel data from 122 quoted Nigerian companies, [31] find ethnicity diversity directors does not give a significant value on company performance. Study in Malaysia, [13] investigate the effect of board diversity as measured by gender and ethnicity diversity on total directors' remuneration. They find that gender diversity has a positive effect on total directors' remuneration but ethnicity diversity has a negative effect on total directors' remuneration.

Thus, the second hypothesis of the current study is as can be seen bellow:

H2: Ethnic diversity of directors improve market performance.

\subsection{Skill diversity}

Skill diversity of directors means that the variation in skill that directors bring into the company. According to [35], directors skill has significant impact on shareholders return, but it has been ignored in the research. In addition, [36] notes that skill directors have better influence on company performance more than intellectual abilities. Better managerial skill of directors improve their confidence in choosing the strategy which would maximize the return of shareholders [35]. [37] argue that financial skill of directors will improve the ability of directors in monitoring and finally increase company performance. In addition, [38] note that directors must have technical skill that allow the directors to train, direct, and evaluate for performs the specific job. In contrast, lack of skill of 
directors members cause too slowly in problem-solving because of they do not have experience to solve the problem.

Prior research of [38] classify directors skill into five skill that are technical, human, communication, conceptual, and emotional intelligence skill for 204 directors and employees in predicting effectiveness of directors. They find that directors skill as measured by five types of skill have a positive impact in predicting effectiveness of directors. [4] find experience diversity directors has a negative relationship with company performance in sudden and gradual crises. Study in Malaysia, [35] investigate the effect of directors' skill by measure with education level and number of experience years for 400 companies from 2000-2009. They find directors' skill has a positive and significant impact on shareholders return.

[23] examine the effect of experience diversity of independent directors and company performance. They employ eight types of directors' experience: financial, accountant, manufacturing, organization members, professors, goverment, attorney and media and research institutes. They find the positive relationship between government experience and company performance. Independent directors with accountants or financial experience has a negative impact on company performance.

Furthermore, the third hypothesis is can be seen bellow:

H3: Skill diversity of directors improve market performance.

\section{Research Method}

The population of the current study is manufacturing companies listed on Indonesia Stock Exchange for 2013-2016 periods. The number sample of this study is 360 company-year observations. For the dependent variable is market performance as measured by Tobin's Q. According [39], Tobin's Q produces a viewing window into the company through the market value of the securities issued and captures the longterm impact of company actions. Other researchers,[2] note that the value of future cash flows, which are captured in the market value of company's assets can be predicted by using Tobin's Q. [40] use the ratio of market value of equity plus total debt divide total assets. Thus, the calculation of Tobin's $Q$ can be shown below:

$$
\text { Tobin's } Q=\frac{\text { Market value of equity }+ \text { total debt }}{\text { Total assets }}
$$

Folowing prior study of [2] and [14], this study uses Blau index to measure directors' diversity variables (gender, ethnic and skill directors). According to [41], Blau index is an appropriate measure for heterogeneity. Blau index has no negative value. It range 
of value is zero point to represent homogeneity in the sample data until less than 1 for bigger numbers for higher diversity.

$$
\text { Blau index }=1-\sum_{i=1}^{n} P i^{2}
$$

For gender diversity, the value of this index if from 0 to 0.5 . The score is 0 if no gender diversity. The score will 0.5 if the number of women and man directors are equal. For ethnic diversity is categorized into 3 that is Chinese, foreign directors, and others. The range value of ethnic diversity is from 0 to 0.666 . Biger value of this index shows greater ethnic diversity of directors [14].

Previous study of [35] measure managerial skill of directors by education level and the number of experience years. While, [42] employ Blau index to measure foreign experience diversity of directors. Thus, this study uses Blau index to examine the skill diversity of directos. It categorized into three of educational background that is business, engineering, and others educational background. The value of skill diversity is ranged into 0 to 0.666 . Biger value of this index shows greater skill diversity of directors.

$$
\mathrm{MP}=\alpha+\beta_{1} \text { Gender }+\beta_{2} \text { Ethnic }+\beta_{3} \text { Skill }+\mathrm{e}
$$

MP = Market performance as measured by Tobin's $Q$

Gender $=$ Gender diversity of directors

Ethnic $=$ Ethnic diversity of directors

Skill = Skill diversity of directors

\section{Result and Discussion}

Table 1. demonstrates the descriptive statistics of this study. The mean Tobin's $Q$ is 1.667 with minimum score is -0.187 and maximum score is 27.212 . The average value of gender diversity is 0.134 and maximum score is 0.500 . The minimum score of gender diversity is 0 , it indicates that no gender diversity on board members in a company. For the ethnic, the means value is around 0.242 . The maximum and minimum score of ethnic diversity are 0.640 and 0.000 . While, the average of skill diversity is 0.463 with maximum value is 0.666 .

The next step before conduct analysis is to test for normality, multicollinearity, and heteroscedasticity. This study employed Jargue Bera in order to test normality. The result showed that probability of Jarque bera is higher than 0.05 . Thus, the data is predicted to be normal. VIF and Breusch Pagan Godfrey are used for multicollinearity and 
TABLE 1: Descritive Statistics.

Mean
Median
Maximum
Minimum
Std. Dev.
Observations

\begin{tabular}{|c|}
\hline TOBIN'S Q \\
\hline 1.667 \\
\hline 0.801 \\
\hline 27.212 \\
\hline-0.187 \\
\hline 2.780 \\
\hline 360 \\
\hline
\end{tabular}

\begin{tabular}{|c|}
\hline GENDER \\
\hline 0.134 \\
\hline 0.000 \\
\hline 0.500 \\
\hline 0.000 \\
\hline 0.186 \\
\hline 360 \\
\hline
\end{tabular}

\begin{tabular}{|c|}
\hline ETHNIC \\
\hline 0.242 \\
\hline 0.320 \\
\hline 0.640 \\
\hline 0.000 \\
\hline 0.230 \\
\hline 360 \\
\hline
\end{tabular}

\begin{tabular}{|l|}
\hline SKILL \\
\hline 0.463 \\
0.480 \\
0.666 \\
0.000 \\
0.168 \\
\hline 360 \\
\hline
\end{tabular}

heteroscedasticity test. The result of VIF is lower than 10 and Breusch Pagan Godfrey's result is higher than 0.05 . It indicates that no multicollinearity and heteroscedasticity problem of the data. In addition, the common rule of thumb for VIF is that the value of VIF not more than 10 in order to clear from multicollinearity problem [43]. The Hausman test is employed in order to choose fixed or random effect model [44].

TABLE 2: Hausman Test.

Test Summary
Cross-section random

Chi-Sq. Statistic
8.252

Chi-Sq. d.f.
3

\begin{tabular}{|c|}
\hline P value \\
\hline 0.041
\end{tabular}

Using panel data analysis, Table 3 shows the main findings of this study for fixed effects model. This study find insiginificant impact between gender on market performance. This finding is opposite with [12]. They propose that adding women in top management and boardroom for 54 large Colombian public companies in period 2008-2015 have positive impact on business performance as measured by Return on Assets (ROA) and Return on Equity (ROE). However, the current study supports the statement of prior work of [28] who perceived that adding women on Board of Directors do not give positve impact on market performance.

The next variables is ethnic diversity. Ethnic diversity is found to reduce the market performance of the company. The negative relationship between ethnic diversity and market performance may suggest that increase ethnic diversity directors will lowering market performance. This negative finding supports the statement that ethnicity diversity creates unsatisfied within directors members [45] and increase conflict and employee turnover [46]. Prior study of [13] also find a negative relationship between ethnicity diversity and total directors' remuneration for 1,094 company-year sample. The third variables is skill diversity. This study find insiginificant impact between skill diversity on market performance as measured by Tobin's $Q$. This result is contradict with prior 
work of Matemilola et al [35] who found that managerial skill of directors has a positive and significant impact on shareholders' return.

TABLE 3: The Result of Fixed Effect Model.

\begin{tabular}{l|c|c|c|c|} 
Variable & Coefficient & Std. Error & t-Statistic & P value \\
\hline C & 2.603 & 0.392 & 6.635 & 0.000 \\
\hline GENDER & -0.316 & 0.653 & -0.483 & 0.629 \\
\hline ETHNIC & -1.957 & 0.846 & -2.311 & $0.021^{* *}$ \\
\hline SKILL & -0.904 & 0.563 & -1.603 & 0.110 \\
\hline$R^{2}$ & 0.94 & & & \\
\hline Adj. ${ }^{2}$ & 0.91 & & & \\
\hline F value & 0.00 & & & \\
\hline Note: & \\
\hline
\end{tabular}

\section{Conclusion}

In the current study proposes that gender diversity and skill diversity do not give benefit to market performance. Since, Indonesia has more than 400 ethnic group. It has a national motto that is "Bhinneka Tunggal Ika" (unity in diversity), but the result of the current study shows that ethnic diversity of directors give a negative impact on market performance. It because ethnicity diversity creates unsatisfied within board members [45] and increase conflict and employee turnover [46]. The result of this paper produces to the regulators to add some norma or ethic in term of ethnic diversity that related with Indonesia's motto "unity diversity". In addition future research may investigate further the role of diversity on Supervisory Board in enhancing better corporate governance.

\section{Acknowledgement}

We would like to thanks to Chairman of Yayasan Perguruan Tinggi Komputer (YPTK) and Rector of Universitas Putra Indonesia "YPTK for significant supporting in term of finance and others.

\section{References}

[1] O. Bordean and A. Borza. (2017). Boards'Attributes and Company Performance: the Romanian Expereience. Economics \& Sociology, vol. 10, no. 2, pp. 61-73. 
[2] M. Kagzi and M. Guha. (2018). Does Board Demographic Diversity Influence Firm Performance? Evidence from Indian-Knowledge Intensive Firms. Benchmarking, vol. 25, no. 3, pp. 1028-1058.

[3] B. S. Coffey and J. Wang. (1998). Board Diversity and Managerial Control as Predictors of Corporate Social Performance. Journal of Business Ethics, vol. 17, no. 14, pp. 15951603.

[4] C. Ooi, C. Hooy, and A. P. M. Som. (2017). The Influence of Board Diversity in Human Capital and Social Capital in Crisis. Managerial Finance, vol. 43, no. 6, pp. 700-719.

[5] D. Carter, B. Simkins, and W. Simpson. (2003). Corporate Governance, Board Diversity, and Firm Value. The Financial Review, vol. 38, no. 1, pp. 33-53.

[6] N. Van Der Walt, C. Ingley, G. S. Shergill, and A. Townsend. (2006). Board Configuration: are Diverse Boards Better Boards? Corporate Governance, vol. 6, no. 2, pp. 129-147.

[7] S. E. Jackson and A. Joshi. (2004). Diversity in Social Context: a Multi-Attribute, Multilevel Analysis of Team Diversity and Sales Performance. Journal of Organizational Behavior, vol. 25, no. April, pp. 675-702.

[8] T. Simons and L. H. Pelled. (1998). Understanding Executive Diversity. Human Resource Planning, pp. 49-51.

[9] M. J. Lenard, B. Yu, E. A. York, and S. Wu. (2014). Impact of Board Gender Diversity on Firm Risk. Managerial Finance, vol. 40, no. 8, pp. 787-803.

[10] D. Abad, M. E. Lucas-pérez, A. Minguez-vera, and J. Yagüe. (2017). Does Gender Diversity on Corporate Boards Reduce Information Asymmetry in Equity Markets. Bussiness Research Quarterly, vol. 20, pp. 192-205.

[11] Y. Thams, B. L. Bendell, and S. Terjesen. (2018). Explaining Women's Presence on Corporate Boards: The Institutionalization of Progressive Gender-Related Policies. Journal of Business Research, vol. 86, no. may, pp. 130-140.

[12] J. Moreno-Gómez, E. Lafuente, and Y. Vaillant. (2018). Gender Diversity in the Board, Women's Leadership and Business Performance. Gender in Management: An International Journal, vol. 33, no. 2, pp. 104-122.

[13] W. E. A. Abdul, M. M. Marzuk, S. B. Jaafar, and T. A. Masron. (2018). Board Diversity and Total Directors' Remuneration: Evidence from an Emerging Market. Pacific Accounting Review, vol. 30, no. 2, pp. 243-272.

[14] N. H. Wellalage, S. Locke, and F. Scrimgeour. (2012). The Global Financial Crisis Impact on Ethnic Diversity of Sri Lanka Boards. Asian Journal of Finance \& Accounting, vol. 4, no. 1, pp. 52-69. 
[15] Y. G. Shan and R. P. Mclver. (2011). Corporate Governance Mechanisms and Financial Performance in China: Panel Data Evidence on Listed Non Financial Companies. Asia Pacific Business Review, vol. 17, no. 3, pp. 301-324.

[16] C. Jungmann. (2006). The Effectiveness of Corporate Governance in One-Tier and Two-Tier Board Systems - Evidence from the UK and Germany - by ECFR, pp. 426474.

[17] A. A. Berle and G. C. Means. (1932). The modern corporation and private property. Macmillan, New York.

[18] M. Jensen and W. Meckling. (1976). Theory of the Firm: Managerial Behavior, Agency Costs, and Ownership Structure. Journal of Financial Economics, vol. 3, no. 4, pp. 305-360.

[19] J. P. Wanous and M. A. Youtz. (1986). Solution Diversity and The Quality of Group Decisions. Acedemy of Management Journal, vol. 29, no. 1, pp. 149-159.

[20] M. Ali and A. M. Konrad. (2017). Antecedents and Consequences of Diversity and Equality Management Systems: The Importance of Gender Diversity in the TMT and Lower to Middle Management. European Management Journal, vol. 35, no. 4, pp. $440-453$.

[21] N. A. Amran and A. C. Ahmad. (2010). Corporate Governance Mechanisms and Performance: Analysis of Malaysian Family and Non-Family Controlled Companies. Journal of Modern Accounting and Auditing, vol. 6, no. 2, pp. 1-15.

[22] L. Zhang. (2012). Board Demographic Diversity, Independence, and Corporate Social Performance. Corporate Governance, vol. 12, no. 5, pp. 686-700.

[23] H. Kim and C. Lim. (2010). Diversity, Outside Directors and Firm Valuation: Korean Evidence. Journal of Business Research, vol. 63, no. 3, pp. 284-291.

[24] S. Darmadi. (2013). Do Women in Top Management Affect Firm Performance? Evidence from Indonesia. Corporate Governance, vol. 13, no. 3, pp. 288-304.

[25] Zaitul and D. Ilona. (2018). Gender in Audit Committee and Financial Reporting Timeliness: the Case of Unique Continental European Model," International Journal of Engineering \& Technology, vol. 7, no. 2.29, pp. 436-442.

[26] S. Pathan and R. Faff. (2013). Does Board Structure in Banks Really Affect Their Performance? Journal of Banking \& Finance, vol. 37, no. 5, pp. 1573-1589.

[27] G. Willows and M. van der Linde. (2016). Women Representation on Boards: a South African Perspective. Meditari Accountancy Research, vol. 24, no. 2, pp. 211-225.

[28] K. A. Farrell and P. L. Hersch. (2005). Additions to Corporate Boards: The Effect of Gender. Journal of Corporate Finance, vol. 11, no. 1-2, pp. 85-106. 
[29] L. T. W. Cheng, R. Y. K. Chan, and T. Y. Leung. (2010). Management Demography and Corporate Performance: Evidence from China. International Business Review, vol. 19, no. 3, pp. 261-275.

[30] C. Shrader, V. Blackburn, and P. Iles. (1997). Women in Management and Firm Financial Performance: An Exploratory Study. Journal of Managerial Issues, vol. 9, no. 3, pp. 355-372.

[31] A. Ujunwa, C. Okoyeuzu, and I. Nwakoby. (2012). Corporate Board Diversity and Firm Performance: Evidence from Nigeria. Review International Comparative Management, vol. 13, no. 4, pp. 605-620.

[32] www.worldpopulationreview.com/countries/indonesia-population. 26 June 2018. 11.42 wib.

[33] D. A. Carter, F. D'Souza, B. J. Simkins, and W. G. Simpson. (2010). The Gender and Ethnic Diversity of US Boards and Board Committees and Firm Financial Performance. Corporate Governance: An International Review, vol. 18, no. 5, pp. 396414

[34] M. A. Harjoto, I. Laksmana, and R. Lee. (2015). The Impact of Demographic Characteristics of CEOs and Directors on Audit Fees and Audit Delay. Corporate Governance, vol. 30, no. 8/9.

[35] B. T. Matemilola, A. N. Bany-Ariffin, and W. N. W. Azman-Saini. (2013). Impact of Leverage and Managerial Skills on Shareholders' Return. Procedia Economics and Finance, vol. 7, no. Icebr, pp. 103-115.

[36] A. Carmeli and A. Tishler. (2006). The Relative Importance of the Top Management Team's Managerial Skills. International Journal of Manpower, vol. 27, no. 1, pp. 9-36.

[37] J. Erickson, Y. W. Park, J. Reising, and H. H. Shin. (2005). Board Composition and Firm Value Under Concentrated Ownership: The Canadian Evidence. Pacific- Basin Finance Journal, vol. 13, no. 4, pp. 387-410.

[38] R. Muthuveloo, K. C. Chiek, and T. A. Ping. (2017). An Empirical Analysis of the Perceived Skills in Predicting Managerial Effectiveness: The Malaysian Perspective. Global Business and Management Research. An International Journal, vol. 9, no. 4s, pp. 41-60.

[39] Y. Hu and S. Izumida. (2008). Ownership Concentration and Corporate Performance: A Causal Analysis with Japanese Panel Data. Corporate Governance, vol. 16, no. 4, pp. 342-358.

[40] L. F. Klapper and I. Love. (2004). Corporate Governance, Investor Protection, and Performance in Emerging Markets. Journal of Corporate Finance, vol. 10, no. 5, pp. 703-728. 
[41] T. Miller and M. Del Carmen Triana. (2009). Demographic Diversity in the Boardroom: Mediators of the Board Diversity-Firm Performance Relationship. Journal of Management Studies, vol. 46, no. 5, pp. 755-786.

[42] S. Kaczmarek, S. Kimino, and A. Pye. (2012). Antecedents of Board Composition: The Role of Nomination Committees. Corporate Governance: An International Review, vol. 20, no. 5, pp. 474-489.

[43] D. Gujarati. (1995). Basic Econometric. Singapore: McGraw-Hill.

[44] J. A. Hausman. (1978). Specification Tests in Econometrics. Econometrica, vol. 46, no. 6, pp. 1251-1271.

[45] F. J. Milliken and L. L. Martins. (1996). Searching for Common Treads: Undertanding the Multiple Effects of in Organizational Diversity. Academy of Management Review, vol. 21, no. 2, pp. 402-433.

[46] T. Kochan, K. Bezrukova, R. Ely, S. Jackson, A. Joshi, K. Jehn, J. Leonard, D. Levine, and D. Thomas. (2003).The Effects of Diversity on Business Performance: Report of the Diversity Research Network. Human Resource Management, vol. 42, no. 1, pp. $3-21$.

\section{About the authors}

Desi llona is senior lecturer of economic faculty, Universitas Putra Indonesia "YPTK" Padang. She completed her PhD at Universiti Utara Malaysia. Her research area is corporate governance. Zerni Melmusi and Elfiswandi are also senior lecturer of economic faculty, Universitas Putra Indonesia "YPTK" Padang. They completed their PhD at Universitas Persada Indonesia. 